\title{
THE FUTURE OF ENTREPRENEURSHIP IN INDONESIA: FOSTERING THE MILLENNIALS' ENTREPRENEURIAL INTENTION
}

\author{
Elkana Timotius ${ }^{* 1}$ \\ ${ }^{*}$ Department of Industrial Engineering, Universitas Kristen Krida Wacana \\ Jl. Tanjung Duren Raya 4, Jakarta Barat 11470, Indonesia
}

\begin{abstract}
Employment opportunities are unbalanced due to the addition of workers each year. Without proper management, this condition may increase unemployment, burdening the country's economy. Therefore, the entrepreneurial intention needs to be fostered for millennials to overcome the intense competition in the labor market. This quantitative study aims to identify the factors that influence the millennial's entrepreneurial intention in Indonesia in order to foster them appropriately. The survey was conducted in May-June 2021, involving 100 randomly selected respondents aged between 25 and 40 in Indonesia. A questionnaire with twenty-six questions was used to identify the right strategy for fostering entrepreneurial intention among millennials. Entrepreneurial knowledge, entrepreneurial orientation, and entrepreneurial efficacy were the three independent variables in this study. They were mediated by the entrepreneurial mindset on entrepreneurial intention as the dependent variable in path analysis, with family support as the moderating variable. Moreover, fifteen hypotheses were tested and accepted by statistical analysis using SmartPLS. The results showed that entrepreneurial knowledge, entrepreneurial orientation, and entrepreneurial efficacy affected the formation of the entrepreneurial mindset, influencing the growth of entrepreneurial intention. Furthermore, family support strengthened the effect of each relationship between these variables. However, family support could be limited by the millennials' unique characteristics and psychological development.
\end{abstract}

Keywords: entrepreneurial knowledge, entrepreneurial orientation, entrepreneurial efficacy, entrepreneurial mindset, millennial's entrepreneurship

\begin{abstract}
Abstrak: Ketersediaan lapangan kerja tidak seimbang dengan penambahan jumlah tenaga kerja setiap tahunnya. Kondisi tersebut bila tidak diantisipasi akan memperbesar peluang terjadinya peningkatan jumlah pengangguran yang semakin membebani perekonomian negara. Minat berwirausaha perlu ditumbuhkan, khususnya bagi generasi milenial, agar bisa menjadi solusi di tengah ketatnya persaingan di pasar tenaga kerja. Tujuan dari penelitian kuantitatif ini adalah untuk mengidentifikasi faktor-faktor yang mempengaruhi minat generasi milenial di Indonesia untuk berwirausaha. Ada 100 orang berusia antara 25 dan 40 tahun di Indonesia yang dipilih secara acak untuk menjadi responden penelitian kuantitatif ini pada bulan Mei-Juni 2021. Kuesioner dengan duapuluh enam pertanyaan disebar untuk mengidentifikasi strategi yang tepat agar dapat memicu minat berwirausaha pada generasi milenial di Indonesia. Pengetahuan kewirausahaan, orientasi kewirausahaan, dan keyakinan kewirausahaan merupakan tiga variabel bebas pada kerangka konseptual analisa jalur yang dianalisis. Ketiganya dimediasi oleh pola pikir kewirausahaan terhadap minat berwirausaha sebagai variabel terikat, sedangkan dukungan keluarga menjadi variabel moderasinya. Analisa statistik dengan menggunakan SmartPLS menerima keseluruhan limabelas hipotesis penelitian yang ditetapkan. Temuan yang dihasilkan menunjukkan bahwa pengetahuan kewirausahaan, orientasi kewirausahaan, dan keyakinan kewirausahaan berpengaruh dalam pembentukan pola pikir kewirausahaan yang selanjutnya berpengaruh terhadap penumbuhan minat berwirausaha. Dukungan keluarga terindikasi dapat memperkuat pengaruh dari setiap hubungan antar variabel tersebut. Namun, temuan penelitian ini juga mengingatkan batasanbatasan dukungan keluarga yang dapat diberikan dengan mempertimbangkan karakteristik dan perkembangan psikologis generasi milenial yang unik.
\end{abstract}

Kata kunci: pengetahuan kewirausahaan, orientasi kewirausahaan, keyakinan kewirausahaan, pola pikir kewirausahaan, kewirausahaan milenial

\footnotetext{
${ }^{1}$ Corresponding author:

Email:mr.elkana@gmail.com; elkana.timotius@ukrida.ac.id
} 


\section{INTRODUCTION}

Indonesia has 273 million people, which is $3.51 \%$ of the world's population (worldometer, 2021). This means that Indonesia is ranked fourth globally by population, after China, India, and the USA. Unfortunately, the annual population growth of $1.07 \%$ is not accompanied by a significant increase in resource availability and production capacity, leading to higher unemployment rates. It is reflected when this country loses uppermiddle income status amid pandemics. The World Bank downgraded Indonesia to lower-middle income status as of July 1, 2021, with a gross national income per capita of $\$ 3,870$ (Jiao and Sihombing, 2021). This condition continues to increase yearly due to the addition of workers without expanding employment capacity, inhibiting development and national economic growth (Dongoran et al. 2016; Hartanto and Masjkuri, 2017; Priastiwi and Handayani, 2019; Sugiyanto, 2006).

Since there is unemployment in almost all countries, there is a need for remedial courses of action. Limited employment opportunities for university graduates cause unemployment exacerbated by the decreasing need for the industry to absorb fresh graduates. Therefore, creative economic development should be increasingly promoted for millennials between 25 and 40 years to be productive for entrepreneurship with the attitude, mentality, and spirit of entrepreneurship to solve problems using their resources. Also, they should identify and take advantage of opportunities to be productive and have added value (Suryana, 2013).

The entrepreneurial intention needs to be driven by a mindset, which determines a person's success in business using the increasingly many opportunities in this modern era. For instance, Forbes noted that 2,755 billionaires worldwide experienced an increase of more than $60 \%$ in their total wealth in 2021 compared to the previous year, to 13.1 trillion USD. Moreover, there has been an addition of 660 billionaires despite the pandemic (Dolan, 2021), and most of them develop their businesses using technological opportunities.

Entrepreneurial intention and mindset are developed individually or formed through support from people, such as family members by inspiring someone to become an entrepreneur. According to Putra and Ramantha (2021) and Setiabudi (2019), the entrepreneurial mindset is formed, intention grows, and develops better when the person is in a family environment. For instance, the parents' attitudes and roles could influence their children's career decisions. According to Marini and Hamidah (2014), support for entrepreneurship could be moral, such as opportunities, trust, ideas, or material support, including business capital, tools, equipment, and location. Therefore, a supportive family promotes the entrepreneurial intention of an individual.

Entrepreneurial intention also needs to be supported by the knowledge possessed, shaping a person's mindset, attitudes, and actions when deciding to become an entrepreneur. Although coincidence and luck sometimes trigger someone to succeed, knowledge is essential because entrepreneurship depends not only on intuition. The intense business competition requires quick, analytical, and logical decisions.

Lumpkin and Dess (1996) stated that entrepreneurial orientation is the ability to identify and exploit opportunities. Furthermore, Miller (2011) defined orientation as the ability to innovate, take risks, and proactively face market changes. Therefore, entrepreneurial orientation builds a company with the right strategy based on existing conditions. Companies based on orientation can innovate (Miller and Friesen, 1983) and are willing to take risks independent of past strategies (Lumpkin and Dess, 1996). Therefore, orientation is essential for a company's survival in an increasingly dynamic environment.

Running a business with various risks is not easy, and an entrepreneur must have the self-efficacy to run the business. This is in line with Bandura (1986), which stated that efficacy is related to a person's ability to execute plans to achieve their goals. Furthermore, Mustofa and Ekawati (2017) stated that efficacy helps entrepreneurs make decisions amid uncertainty.

The competencies of its current millennials determine the future of a nation. In the modern era, with technological advances, millennials need to be more creative, aiming to find work and see opportunities and create jobs. Millennials that wait for a job increase a country's burden, especially in the new normal life after the COVID-19 pandemic. Rapid changes are set to occur, requiring adaptation from millennials as a country's foundation. Therefore, this study identifies the factors fostering the entrepreneurial intention of millennials in Indonesia because they are significant for a country's progress. Millennials were selected as study objects because they account for $53.81 \%$ of the 
population in Indonesia. Moreover, the entrepreneurial intention was examined for its effect on knowledge, orientation, and efficacy. These three factors were mediated by an entrepreneurial mindset and moderated by family support.

\section{METHODS}

This study empirically examined the importance of entrepreneurial intention for millennials in Indonesia. Various literature on theories related to intention shows an urgency to predict the future of the entrepreneurial climate in Indonesia. The question that needs to be answered is on how to foster entrepreneurial intention for millennials. Therefore, this study quantitatively analyzes the variables affecting Entrepreneurial Intention $(\mathrm{Y})$ as the dependent variable. Figure 1 shows the research framework from the theoretical study results. Three independent variables, one moderating variable, and one mediating variable were analyzed using multiple linear regression. Entrepreneurial Knowledge (X1), Entrepreneurial Orientation (X2), and Entrepreneurial Efficacy (X3) are independent variables, Entrepreneurial Mindset $(Z)$ is the mediating variable, while Family Support (M) is the moderating variable. All research variables contain indicators to gather relevant data as shown in Table 1.

Fifteen hypotheses are established in this study based on the research framework formed, including:

H1 : Entrepreneurial Knowledge (X1) has a significant and positive direct effect on Entrepreneurial Intention (Y) that moderated by Family Support
(M)

H2 : Entrepreneurial Knowledge(X1) has a significant and positive direct effect on Entrepreneurial Intention (Y)

H3 : Entrepreneurial Knowledge (X1) has a significant and positive direct effect on Entrepreneurial Mindset (Z)

H4 : Entrepreneurial Orientation (X2) has a significant and positive direct effect on Entrepreneurial Intention (Y) that moderated by Family Support (M)

H5 : Entrepreneurial Orientation(X2) has a significant and positive direct effect on Entrepreneurial Intention (Y)

H6 : Entrepreneurial Orientation (X2) has a significant and positive direct effect on Entrepreneurial Mindset (Z)

H7 : Entrepreneurial Efficacy (X3) has a significant and positive direct effect on Entrepreneurial Intention (Y) that moderated by Family Support (M)

H8 : Entrepreneurial Efficacy (X3) has a significant and positive direct effect on Entrepreneurial Intention (Y)

H9 : Entrepreneurial Efficacy (X3) has a significant and positive direct effect on Entrepreneurial Mindset (Z)

H10 : Entrepreneurial Mindset (Z) has a significant and positive direct effect on Entrepreneurial Intention (Y) that moderated by Family Support (M)

H11 : Entrepreneurial Mindset (Z) has a significant and positive direct effect on Entrepreneurial Intention $(\mathrm{Y})$

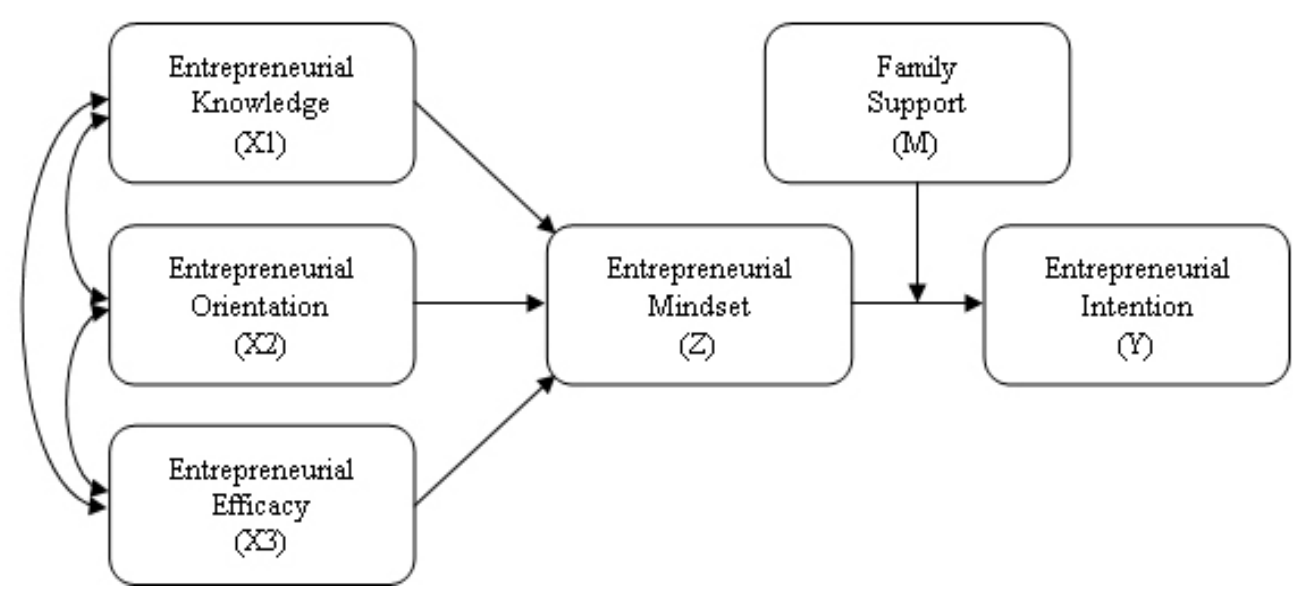

Figure 1. The research framework 
H12 : Family Support (M) has a significant and positive direct effect on Entrepreneurial Intention (Y)

H13 : Entrepreneurial Knowledge (X1) that mediated by Entrepreneurial Mindset (Z) has a significant and positive indirect effect on Entrepreneurial Intention (Y)

H14 : Entrepreneurial Orientation (X2) that mediated by Entrepreneurial Mindset (Z) has a significant and positive indirect effect on Entrepreneurial Intention $(\mathrm{Y})$

H15 : Entrepreneurial Efficacy (X3) that mediated by Entrepreneurial Mindset $(Z)$ has a significant and positive indirect effect on Entrepreneurial Intention $(\mathrm{Y})$
The study was conducted in May-June 2021 to the population that comprised Indonesian citizens aged between 25 and 40 years. Respondents consisted of 100 people selected randomly using the probability sampling method. They were asked twenty-six questions that indicated research variables. Furthermore, Partial Least Squares Structured Equestrian Model (PLS-SEM) and Moderated Regression Analysis (MRA) were used for path analysis. The measurement model tested the validity and reliability, while the structural model tested the causality of each hypothesis predictively.

Table 1. Research variables and indicators

\begin{tabular}{lll}
\hline Variables & Indicators & Sources \\
\hline Entrepreneurial Knowledge (X1) & The know-how about Roles (X1.1) & Clercq and Arenius (2006) \\
& The know-how about Personality (X1.2) & \\
& The know-how about Responsibilities (X1.3) & \\
& The know-how about Business Management (X1.4) & \\
& The know-how about Organization (X1.5) & Lumpkin and Dess (1996) \\
Entrepreneurial Orientation (X2) & Innovative Action (X2.1) & \\
& Proactive Action (X2.2) & \\
& Dare to Take Risk (X2.3) & Wang and Huang (2019) \\
& Dare to Compete (X2.4) & \\
Entrepreneurial Efficacy (X3) & Efficacy in Innovating (X3.1) & \\
& Taking Existing Opportunities (X3.2) & \\
& Building Relationships (X3.3) & \\
& Dealing with Risks (X3.4) and Shepherd (2009) \\
Entrepreneurial Mindset (Z) & Goal Orientation (Z1.5) & \\
& Metacognitive Knowledge (Z1.2) & \\
& Metacognitive Experience (Z1.3) & \\
& Metacognitive Choice (Z1.4) & \\
Entrepreneurial Intention (Y) & Monitoring (Z1.5) & \\
& Emotional Supports (M1.1) et al. (2017) \\
& Appreciation Supports (M1.2) & \\
& Instrumental Supports (M1.3) & \\
& Informational Supports (M1.4) & \\
& Work for Others (Y1.2) & \\
& Career Choice (Y1.3) & \\
& Enjoy Activities (Y1.4) & \\
& & \\
& &
\end{tabular}




\section{RESULTS}

\section{Evaluation of Measurement Model Results}

Convergent Validity

The convergent validity test determines the validity of each indicator that constructs a variable. Indicators of variables are declared valid when they have an outer loading value of more than 0.6 . The convergent validity test results for all indicators using SmartPLS show that all outer loadings have a value of more than 0.6 (Table 2 ). This means that all questions on the questionnaire are valid. Therefore, the respondents' answers to the questionnaire are helpful for analysis.

\section{Discriminant Validity \& Composite Reliability}

The discriminant validity test was performed by comparing each variable's Average Variance Extracted (AVE) value and its correlation with other variables based on the conceptual framework built. The AVE value obtained should be greater than 0.50 to indicate discriminative validity. Furthermore, the composite reliability test determines the true reliability of each variable, whose value should be greater than 0.5 . Table 3 shows the discriminant validity and composite reliability test results. All values generated are more than 0.5, meaning they are valid and reliable for analysis.

Table 2. Result of convergent validity test

\begin{tabular}{lccc}
\hline Variable & Indicator & Outer Loading & Validity \\
\hline Entrepreneurial Knowledge (X1) & $\mathrm{X} 1.1$ & 0.799 & Valid \\
& $\mathrm{X} 1.2$ & 0.764 & Valid \\
& $\mathrm{X} 1.3$ & 0.700 & Valid \\
& $\mathrm{X} 1.4$ & 0.795 & Valid \\
& $\mathrm{X} 1.5$ & 0.739 & Valid \\
Entrepreneurial Orientation (X2) & $\mathrm{X} 2.1$ & 0.811 & Valid \\
& $\mathrm{X} 2.2$ & 0.800 & Valid \\
& $\mathrm{X} 2.3$ & 0.826 & Valid \\
& $\mathrm{X} 2.4$ & 0.768 & Valid \\
Entrepreneurial Efficacy (X3) & $\mathrm{X} 3.1$ & 0.800 & Valid \\
& $\mathrm{X} 3.2$ & 0.845 & Valid \\
& $\mathrm{X} 3.3$ & 0.741 & Valid \\
Entrepreneurial Intention (Y) & $\mathrm{X} 3.4$ & 0.773 & Valid \\
& $\mathrm{Y} 1.1$ & 0.798 & Valid \\
& $\mathrm{Y} 1.2$ & 0.830 & Valid \\
Entrepreneurial Mindset (Z) & $\mathrm{Y} 1.3$ & 0.794 & Valid \\
& $\mathrm{Y} 1.4$ & 0.822 & Valid \\
Entrepren & $\mathrm{Z} 1.1$ & 0.761 & Valid \\
Entrepreneurial Mindset (Z) * Family Support (M) & $\mathrm{Z} 1.2$ & 0.747 & Valid \\
& $\mathrm{Z} 1.3$ & 0.729 & Valid \\
& $\mathrm{Z} 1.4$ & 0.767 & Valid \\
& $\mathrm{Z} 1.5$ & 0.819 & Valid \\
& $\mathrm{M} 1.1$ & 0.859 & Valid \\
& $\mathrm{M} 1.2$ & 0.824 & Valid \\
& $\mathrm{M} 1.3$ & 0.830 & Valid \\
& $\mathrm{M} 1.4$ & 0.791 & Valid \\
\hline
\end{tabular}




\section{Structural Model Evaluation}

\section{R-Square Test}

Two structural models are contained in the conceptual framework of this study. The first structural model is the effect of Entrepreneurial Knowledge (X1), Entrepreneurial Orientation (X2), and Entrepreneurial Efficacy (X3) on Entrepreneurial Intention (Y). The second structural model is the effect of Entrepreneurial Knowledge (X1), Entrepreneurial Orientation (X2), Entrepreneurial Efficacy (X3), and Entrepreneurial Intention (Y) on the Entrepreneurial Mindset (Z). The $\mathrm{R}$-Square test was performed to determine the effect of the independent variables on each structure.

Table 4 shows the R-Square test results for each structure. The results show that Entrepreneurial Knowledge (X1), Entrepreneurial Orientation (X2), and Entrepreneurial Efficacy (X3) affect Entrepreneurial Intention (Y) by $64.3 \%$. Other variables outside this study influence the remaining $35.7 \%$. Furthermore, Entrepreneurial Knowledge (X1), Entrepreneurial Orientation (X2), and
Entrepreneurial Efficacy (X3) affect Entrepreneurial Mindset (Z) by $52.3 \%$, while other variables outside this study influence $47.7 \%$.

\section{Hypothesis Test}

Therearefifteen hypotheses of the resulting relationships between variables in the conceptual framework. The hypothesis test was performed to obtain T-statistics and $p$-values. The t-statistic value of more than 0.05 indicates the effect of one variable on other variables, or the hypothesis is accepted when the error tolerance is $5 \%$. The effect is significant when the p-value is less than or equal to 0.05 . They are considered to be significant at the $5 \%$ level because the data are not to be obtained with high accuracy resources, there is a $5 \%$ probability that the results occurred by chance. Figure 2 shows the hypothesis test results, and Table 5 summarizes the conclusions of each hypothesis tested. The results show that all hypotheses are accepted, meaning that each variable has an effect, though each relationship has a different direction and significance.

Table 3. Result of validity discriminant and composite reliability test

\begin{tabular}{lcccc}
\hline & $\begin{array}{c}\text { Cronbach's } \\
\text { Alpha }\end{array}$ & rho_A & $\begin{array}{c}\text { Composite } \\
\text { Reliability }\end{array}$ & $\begin{array}{c}\text { Average Variance } \\
\text { Extracted (AVE) }\end{array}$ \\
\hline Entrepreneurial Knowledge (X1) & 0.817 & 0.823 & 0.872 & 0.578 \\
Entrepreneurial Knowledge (X1) * Family Support & 1.000 & 1.000 & 1.000 & 1.000 \\
(M) & & & & \\
Entrepreneurial Orientation (X2) & 0.814 & 0.815 & 0.878 & 0.642 \\
Entrepreneurial Orientation (X2) * Family Support & 1.000 & 1.000 & 1.000 & 1.000 \\
(M) & & & & \\
Entrepreneurial Efficacy (X3) & 0.799 & 0.804 & 0.869 & 0.625 \\
Entrepreneurial Efficacy (X3) * Family Support (M) & 1.000 & 1.000 & 1.000 & 1.000 \\
Entrepreneurial Mindset (Z) & 0.823 & 0.824 & 0.876 & 0.585 \\
Entrepreneurial Mindset (Z) * Family Support (M) & 1.000 & 1.000 & 1.000 & 1.000 \\
Family Support (M) & 0.846 & 0.852 & 0.896 & 0.683 \\
Entrepreneurial Intention (Y) & 0.827 & 0.827 & 0.885 & 0.658 \\
\hline
\end{tabular}

Table 4. Result of R-Square Test

\begin{tabular}{lcc}
\hline & R Square & R Square Adjusted \\
\hline Entrepreneurial Intention (Y) & 0.676 & 0.643 \\
Entrepreneurial Mindset (Z) & 0.537 & 0.523 \\
\hline
\end{tabular}




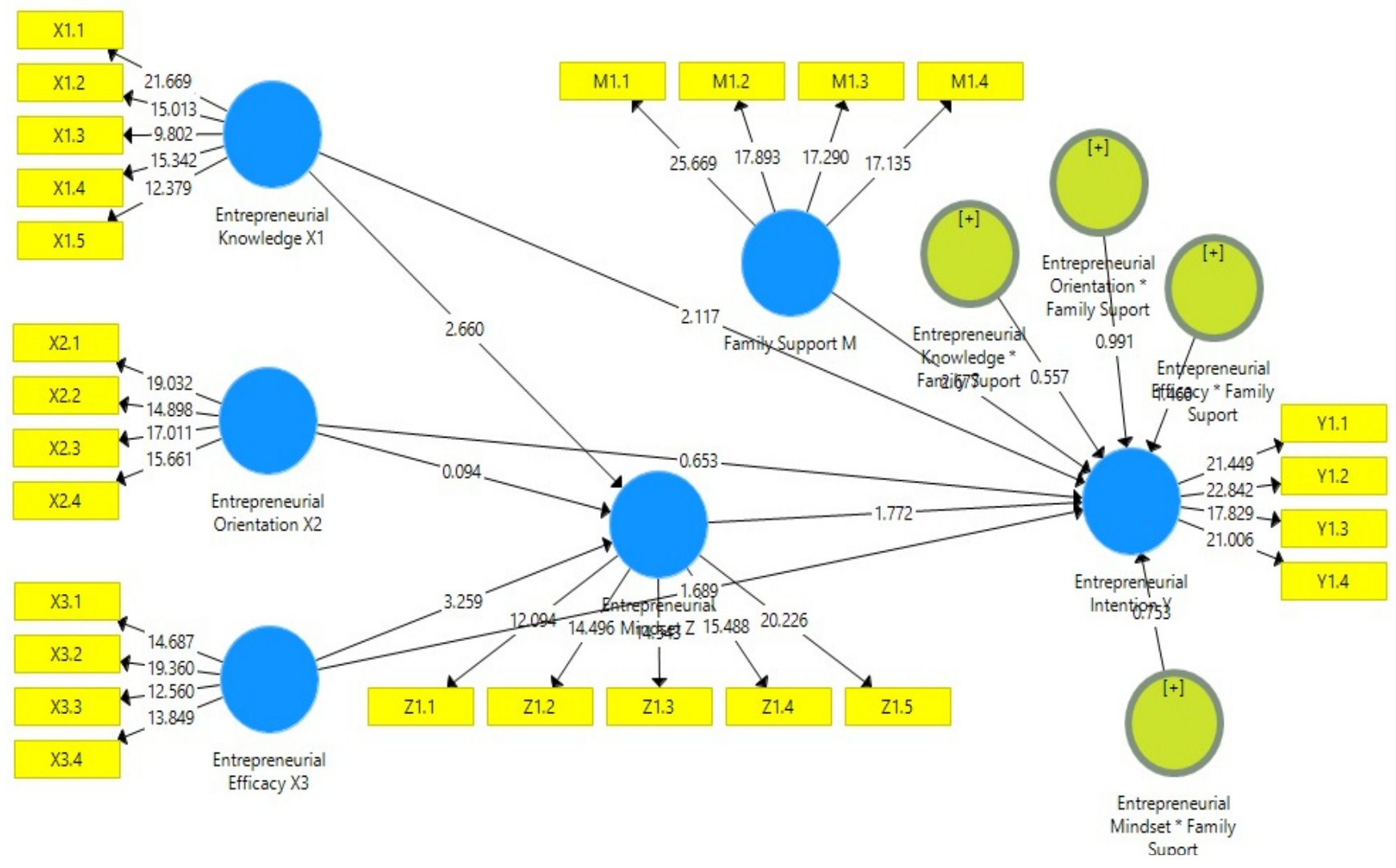

Figure 2. Result of the hypothesis test

Table 5. Summary of hypothesis test

\begin{tabular}{cccccc}
\hline Hypothesis & Beta & T-Values & P-Values & Significancy & Acceptance \\
\hline H1 & 0.103 & 0.557 & 0.020 & Positive Significant & Accepted \\
H2 & 0.272 & 2.117 & 0.035 & Positive Significant & Accepted \\
H3 & 0.434 & 2.660 & 0.008 & Positive Significant & Accepted \\
H4 & 0.053 & 0.991 & 0.002 & Positive Significant & Accepted \\
H5 & -0.043 & 0.653 & 0.014 & Negative Significant & Accepted \\
H6 & -0.024 & 0.094 & 0.025 & Negative Significant & Accepted \\
H7 & -0.125 & 1.460 & 0.045 & Negative Significant & Accepted \\
H8 & 0.193 & 1.689 & 0.002 & Positive Significant & Accepted \\
H9 & 0.370 & 3.259 & 0.001 & Positive Significant & Accepted \\
H10 & 0.089 & 0.753 & 0.020 & Positive Significant & Accepted \\
H11 & 0.222 & 1.772 & 0.007 & Positive Significant & Accepted \\
H12 & 0.292 & 2.677 & 0.008 & Positive Significant & Accepted \\
H13 & 0.097 & 1.304 & 0.019 & Positive Significant & Accepted \\
H14 & -0.004 & 0.085 & 0.003 & Negative Significant & Accepted \\
H15 & 0.081 & 1.593 & 0.012 & Positive Significant & Accepted \\
\hline
\end{tabular}




\section{The Role of Entrepreneurial Knowledge}

The first and second hypotheses are accepted, showing that Entrepreneurial Knowledge (X1) positively affects Entrepreneurial Intention (Y). Also, as a moderating variable, Family Support (M) strengthens this direct effect significantly. This aligns with Rahmah (2017), which stated that family education fosters an individual's intention.

The statistical calculation results show that the third hypothesis is accepted, meaning that Entrepreneurial Knowledge (X1) has a significant positive direct effect on the Entrepreneurial Mindset (Z). It encourages the millennials in Indonesia to equip them with entrepreneurial knowledge when decide to become entrepreneurs. The entrepreneurial knowledge willshape their mindset as entrepreneurs directly and significantly. This is in line with Tanjaya and Radianto (2020), which stated that knowledge enables an entrepreneur to overcome obstacles in business activities. The obstacles include solving conflicts, making decisions, considering risks, seeing opportunities, and developing competitive strategies. This is achieved when the individual has an entrepreneurial mindset.

Entrepreneurial knowledge directly affects entrepreneurial intentions and has a positive and significant indirect effect when mediated by the entrepreneurial mindset. This is indicated by hypothesis 13 , which is accepted through statistical calculations. Entrepreneurial education is a learning process to change students' attitudes and mindset towards career choices (Wedayanti and Giantari, 2016; Wijaya and Dharmayanti, 2016). These findings show that knowledge needs serious attention when individuals develop an entrepreneurial mindset and intention.

\section{The Role of Entrepreneurial Orientation}

The entrepreneurial orientation measured by Miller (2011) is based on innovating, being creative and proactive to business opportunities, competing aggressively, and taking risks. Statistical data shows that hypotheses 4 and 5 are accepted, meaning that Entrepreneurial Orientation (X2) significantly affects Entrepreneurial Intention (Y). This direct effect is different when moderated by the Family Support (M) variable and without moderating. With a negative beta value, the fifth hypothesis indicates that entrepreneurial burdens and challenges reduce Millennials' entrepreneurial intention. However, entrepreneurial orientation increases Millennials' entrepreneurial intention with family support. This is reinforced by Althea and Slamet (2020). The family supports the increased intention, including relationship development, capital assistance, and emotional presence (Baughn et al. 2006; Yurtkoru et al. 2014).

Hypothesis 6 is accepted, though Entrepreneurial Orientation (X2) negatively affects Entrepreneurial Mindset (Z). This is not different when entrepreneurial orientation has a significant negative effect on entrepreneurial intention, meaning that it contains several risks. These difficulties affect the mindset of millennials that dare to take risks without proper consideration. Entrepreneurial orientation is used to formulate strategies and policies in every business action (Rauch et al. 2009). Also, Covin and Slevin (1989) stated that entrepreneurial orientation involves taking risks for a change and innovating to create a competitive advantage.

The accepted hypothesis 14 shows that entrepreneurial orientation affects entrepreneurial intention when mediated by an entrepreneurial mindset. However, its effect is a significant negative indirect effect, similar to the direct effect on the entrepreneurial mindset and entrepreneurial intention. According to Devi (2017), a young generation with a mature orientation easily develops a mindset that fosters intention. Therefore, entrepreneurial orientation should be built carefully because it is the foundation of an entrepreneur's mindset and intention.

\section{The Role of Entrepreneurial Efficacy}

Entrepreneurial efficacy arises and becomes embedded in an individual when planning, starting and running a business. Therefore, an individual with efficacy has an intention. This is in line with Sofia and Sanjaya (2021), which stated that a more robust entrepreneurial efficacy increases an individual's opportunity for success. Specifically, it sharpens skills, inspires confidence, and increases their enthusiasm to succeed. These findings are in line with hypothesis 8, proving that Entrepreneurial Efficacy (X3) has a significant positive and direct effect on Entrepreneurial Intention (Y). However, since efficacy is embedded in a person, other external factors allow it to have a different impact. This is seen from the accepted hypothesis 7 . There is a significant negative direct effect when Family Support (M) moderates 
the relationship between Entrepreneurial Efficacy (X3) and Entrepreneurial Intention (Y). The efficacy could change when individuals identify facts that do not match their expectations. This happens mainly when facts are obtained from people in the immediate environment (Sofia and Sanjaya, 2021). For instance, when individuals see many failures, the initially high efficacy decreases.

Entrepreneurial Efficacy (X3) has a significant positive direct effect on Entrepreneurial Mindset (Z), implying that hypothesis 9 is accepted. This finding is not surprising because efficacy and mindset are an individual's internal psychological factors. Similarly, Winnaar and Scholtz (2019) stated that self-confidence shapes the mindset, influencing their attitudes and actions when running a business.

Hypothesis 15 shows that entrepreneurial efficacy positively and significantly indirectly affect entrepreneurial intention when mediated by the entrepreneurial mindset. This strengthens the fact that entrepreneurial efficacy builds a mindset that fosters the Millennials' intention. Similar findings were obtained by Dwijayanti (2015) and Wirawati et al. (2018). Furthermore, Wahyudiono (2016) stated that entrepreneurial efficacy is a determining factor for business success.

\section{The Role of Entrepreneurial Mindset}

Entrepreneurial Mindset (Z) moderated by Family Support(M), or without moderation, significantly affects Entrepreneurial Intention (Y). Therefore, hypotheses 10 and 11 are accepted. This is in line with Purwaningsih and Megaster (2019), which showed that intention depends on the mindset. According to McGrath and MacMillan (2000), mindset is an individual's businessoriented thinking framework. An individual with a mindset prefers uncertainty, views things more simply, and takes risks. Moreover, this mindset familiarizes an individual with difficulties as a learning tool for future activities.

The entrepreneurial mindset is enough to build intention, which needs to be strengthened by family support. Kirkwood (2007) stated that families should provide support in advice, emotional approaches, or greater opportunities. In this regard, family support is essential for millennials in responding to the psychological conditions faced. They need social support and the freedom to show their abilities (Hägg and Kurczewska, 2019).

\section{The Role of Family Support}

This study used Family Support (M) as a moderating and independent variable to analyze Entrepreneurial Intention $(\mathrm{Y})$. The statistical calculation results show a positive and significant direct effect when hypothesis 12 is accepted. This is in line with Rahmah (2017), which stated that greater family support increases entrepreneurial intention. Moreover, Sofia and Sanjaya (2021) stated that families should determine a child's career and provide freedom and confidence to choose their future. Therefore, parents should act as knowledge transferors to their offspring. This is related to the collective culture of the family to help each other to achieve success.

\section{Managerial Implications}

This study could be a guideline to foster the intention of millennials based on the demographics of the respondents involved. Entrepreneurial knowledge and family support contributed greatly to achieving the research objective. It is highly recommended that education about entrepreneurship be increased in the education system in Indonesia and support for family members to become entrepreneurs. Both are the priority to foster the millennial's entrepreneurial intention in Indonesia. Although the calculations were based on statistical rules, deviating from the findings is possible according to the tolerance limits set during data analysis.

\section{CONCLUSIONS AND RECOMMENDATIONS}

\section{Conclusions}

Entrepreneurial education that increases intentions needs serious attention to enable Indonesian millennials to take advantage of opportunities proactively and compete innovatively. Therefore, the education curriculum should be adapted to their character and technological developments. Furthermore, education should convey unidirectional theory and create a discussion that forms the mindset. Millennials adapt to facing challenges and finding solutions. Entrepreneurial 
education is more effective when directly instilled from an early age, starting with simple family practices to foster independence and creativity.

Entrepreneurial orientation negatively affects the Millennials' mindset and reduces their intention in the absence of family support. This is because of their unstable and inconsistent psychological condition. An entrepreneur needs the maturity of attitude and thinking, a character that cannot be realized instantly or learned without practice. Families need to provide support for the orientation maturation process gradually and consistently on an ongoing basis.

Entrepreneurial efficacy is an individual's internal aspect that must be maintained because it is difficult to restore once lost. The environment and the people around have a psychological effect on the individual. Moreover, entrepreneurial failures could change an individual's mindset and cause a loss of self-efficacy. On the contrary, the successes of others could shape the mindset in a better direction and foster intention.

The mindset significantly contributes to entrepreneurial activities. Therefore, Indonesian millennials need first to develop thee mindset when deciding to be entrepreneurs. The decision to become an entrepreneur should not be taken out of compulsion, requests from family, imitation, or luck. The formation of a mindset automatically fosters intention. However, millennials that prefer facing challenges and taking risks need the right direction and advice from family. This prevents the deviation of the mindset to a detrimental direction.

Family support cannot be ignored in fostering entrepreneurial intention. Parents and family members should support a business individual during both success and failure. However, the support should not be excessive because it could create a comfort zone. The right dose of family support optimizes intention. In carrying out entrepreneurial activities, millennials cannot be given many directions, burdened with targets and demands for success, or over-provided with resources. It is necessary to give them trust and freedom for them to carry out their entrepreneurial activities.

\section{Recommendations}

Furthermore, the calculations remind the possibility of the effect from the variables outside this study. Therefore, further studies could use other variables, new respondents, and different conditions. The results are integrated to produce a concrete and comprehensive understanding beneficial for future entrepreneurial climate.

\section{REFERENCES}

Allen TD. 2001. Family-supportive work environments: The role of organizational perceptions. Journal of Vocational Behavior 58:414-435. https://doi. org/10.1006/jvbe.2000.1774

Althea J, Slamet F. 2020. Pengaruh dukungan pendidikan dan dukungan relasi terhadap intensi berwirausaha mahasiswa: Kepercayaan diri sebagai variabel moderator. Jurnal Manajerial dan Kewirausahaan 2(1):141-151. https://doi. org/10.24912/jmk.v2i1.7454

Anisah HU, Wandary W, Claudia M. 2017. The development of entrepreneurial mindset measurement instruments as predictor for Wetland's MSMEs business sustainability. Advances in Economics, Business and Management Research 40:270-280.

Arshad AS, Rasli A, Arshad AA, Zain ZM. 2014. The impact of entrepreneurial orientation on business performance: A study of technology-based SMEs in Malaysia. Procedia - Social and Behavioral Sciences 130:46-53. https://doi.org/10.1016/j. sbspro.2014.04.006

Bandura A. 1978. Reflections on self-efficacy. Advances in Behavioral Research and Therapy 1(4):237-269.https://doi.org/10.1016/01466402(78)90012-7

Bandura A. 1986. The explanatory and predictive scope of self-efficacy theory. Journal of Clinical and Social Psychology 4:359-373. https://doi. org/10.1521/jscp.1986.4.3.359

Baughn CC, Chua B, Neupert KE. 2006. The normative context for women's participation in entrepreneurship: A multicountry study. Entrepreneurship Theory and Practice 30(5). https://doi.org/10.1111/j.15406520.2006.00142.x

Clercq DD, Arenius P. 2006. The role of knowledge in business start-up activity. International Small Business Journal 24(4):339-358. https://doi. org/10.1177/0266242606065507

Covin JG, Slevin DP. 1989. Strategic management of small firms in hostile and benign environments. Strategic Management Journal 10:75-87. https:// 
doi.org/10.1002/smj.4250100107

Devi A. 2017. Peran orientasi kewirausahaan sebagai mediasi antara pendidikan dan minat berwirausaha pada mahasiswa. Jurnal Studi Ekonomi dan Bisnis Islam 2(2):108-130. https:// doi.org/10.31332/lifalah.v2i2.657

Dolan KA. 2021. Forbes' 35th annual world's billionaires list: Facts and figures 2021. https:// www.forbes.com/sites/kerryadolan/2021/04/06/ forbes-35th-annual-worlds-billionaires-listfacts-and-figures-2021/?sh=284a7885e587. [27 June 2021].

Dongoran FR, Nisa K, Sihombing M, Purba LD. 2016. Analisis jumlah pengangguran dan ketenagakerjaan terhadap keberadaan usaha mikro kecil dan menengah di kota Medan. Jurnal EduTech 2(2):59-72.

Dwijayanti R. 2015. Pengaruh pendidikan kewirausahaan, locus of control, dan kebutuhan berprestasi terhadap pembentukan sikap kewirausahaan mahasiswa. Jurnal Ekonomi Pendidikan dan Kewirausahaan 3(2):170-180. https://doi.org/10.26740/jepk.v3n2.p170-180

Friedman DE. 1990. Work and family: The new strategic plan. Human Resources Planning 13:79-89.

Hägg G, Kurczewska A. 2019. Who is the student entrepreneur? Understanding the emergent adult through the pedagogy and andragogy interplay. Journal of Small Business Management 57(8). https://doi.org/10.1111/jsbm.12496

Hartanto TB, Masjkuri SU. 2017. Analisis pengaruh jumlah penduduk, pendidikan, upah minimum dan Produk Domestic Regional Bruto (PDRB) terhadap jumlah pengangguran di kabupaten dan kota provinsi Jawa Timur tahun 2010-2014. Jurnal Ilmu Ekonomi Terapan 2(1):1-11. https:// doi.org/10.20473/jiet.v2i1.5502

Haynie M, Shepherd DA. 2007. Exploring the entrepreneurial mindset: Feedback and adaptive decision-making. Babson College Entrepreneurship Research Conference.

Haynie M, Shepherd DA. 2009. A measure of adaptive cognition for entrepreneurship research. Entrepreneurship Theory and Practice 33(3). https://doi.org/10.1111/j.15406520.2009.00322.x

Jiao C, Sihombing G. 2021. Indonesia loses uppermiddle income status amid pandemic. https:// www.bloomberg.com/news/articles/202107-08/indonesia-loses-prized-upper-middleincome-status-amid-pandemic. [10 July 2021].
Kier AS, McMullen JS. 2016. Entrepreneurial imaginativeness in new venture ideation. Academy of Management Journal 61(6):22652295.

Kirkwood JJ. 2007. Igniting the entrepreneurial spirit: Is the role parents play gendered? International JournalofBehaviour\& Research13(1):39-59.Lee SM, Peterson SJ. 2000. Culture, entrepreneurial orientation, and global competitiveness. Journal of World Business 35(4):401-416.

Lumpkin GT, Dess GG. 1996. Clarifying the entrepreneurial orientation construct and linking it to performance. The Academy of Management Review 21(1):135-172. https://doi. org/10.2307/258632

Marini CK, Hamidah S. 2014. Pengaruh self-efficacy, lingkungan keluarga, dan lingkungan sekolah terhadap minat berwirausaha siswa SMK Jasa Boga. Jurnal Pendidikan Vokasi 4(2):195-207. https://doi.org/10.21831/jpv.v4i2.2545

McGrath RG, MacMillan IC. 2000. The Entrepreneurial Mindset. Boston: Harvard Business School Press.

Miller D. 2011. Miller (1983) revisited: A reflection on EO research and some suggestion for the future. Entrepreneurship Theory and Practice 35(5):873-894.

Miller D, Friesen PH. 1983. Strategy-making and Environment: The third link. Strategic Management Journal 4(3):221-235. https://doi. org/10.1002/smj.4250040304

Mustofa ALA, Ekawati NW. 2017. Keberanian mengambil risiko memediasi pengaruh efikasi diri dan kebutuhan akan prestasi terhadap niat berwirausaha. E-Jurnal Manajemen 6(10):53775405.

Periera A, Mashabi NA, Muhariati M. 2017. Pengaruh dukungan orangtua terhadap minat anak dalam berwirausaha: Pada siswa SMK Strada Koja, Jakarta Utara. Jurnal Kesejahteraan Keluarga dan Pendidikan 4(2):70-76. https://doi. org/10.21009/JKKP.042.04

Priastiwi D, Handayani HR. 2019. Analisis pengaruh jumlah penduduk, pendidikan, upah minimum, dan PDRB terhadap tingkat pengangguran terbuka di provinsi Jawa Tengah. Diponegoro Journal of Economics 1(1):159-169.

Purwaningsih N, Megaster T. 2019. Pengaruh pola pikir kewirausahaan dan adversity quotient terhadap minat berwirausaha: Studi pada mahasiswa Fakultas Ekonomi dan Bisnis Universitas 
Muhammadiyah Tangerang. Simposium Nasional Mulitidisiplin.

Putra CBW, Ramantha IW. 2021. Kepribadian, motivasi, dukungan keluarga dan pendidikan terhadap minat berwirausaha mahasiswa jurusan Akuntansi. E-Jurnal Akuntansi 31(2):324-336.

Rahmah YF. 2017. Entrepreneurial education dan entrepreneurial intention: Social support sebagai moderasi variabel. Jurnal Ilmu Sosial dan Ilmu Politik 7(1):74-82. https://doi.org/10.15575/ jp.v7i1.1737

Ramayah T, Harun Z. 2005. Entrepreneurial intention among the student of Universiti Sains Malaysia (USM). International Journal of Management and Entrepreneurship 1(1):8-20.

Rauch A, Wiklund J, Lumpkin GT, Frese M. 2009. Entrepreneurial orientation and business performance: An assessment of past research and suggestions for the future. Entrepreneurship Theory and Practice 33(3):761-787.

Setiabudi KJ. 2019. Pengaruh dukungan keluarga dan kepribadian wirausaha terhadap niat berwirausaha mahasiswa program studi manajemen terakreditasi " $A$ " pada perguruan tinggi swasta di kota Surabaya. AGORA 7(1).

Shepherd DA, Patzelt H, Haynie JM. 2010. Entrepreneurial spirals: Deviation-amplifying loops of an entrepreneurial mindset and organizational culture. Entrepreneurship Theory and Practice 34(1). https://doi.org/10.1111/ j.1540-6520.2009.00313.x

SofiaA, Sanjaya EL.2021. Entrepreneurial self-efficacy, perceived family support, dan entrepreneurial intention pada mahasiswa. Psibernetika 14(1):49-57.

Sugiyanto. 2006. Implikasi pengangguran terhadap pembangunan nasional serta strategi pemecahannya. Journal of Value Added 2(2):117.

Suryana. 2013. Kewirausahaan: Kiat dan Proses Menuju Sukses. Jakarta: Salemba Empat.

Tanjaya C, Radianto WED. 2020. Entrepreneurial knowledge, entrepreneurial intention, dan entrepreneurial orientation pada pendidikan ilmu akuntansi. Media Akuntansi dan Perpajakan Indonesia 1(2):44-56. https://doi.org/10.37715/ mapi.v1i2.1406

Tshikovhi N, Shambare R. 2015. Entrepreneurial knowledge, personal attitudes, and entrepreneurship intentions among South African Enactus students. Problems and Perspectives in Management 13(1):152-158.

Wahyudiono A. 2016. Pengaruh pendidikan kewirausahaan, pengalaman berwirausaha, dan jenis kelamin terhadap sikap berwirausaha pada mahasiswa Fakultas Ekonomi Universitas Muhammadiyah Surabaya. Jurnal Ekonomi Pendidikan dan Kewirausahaan 4(1):76-91. https://doi.org/10.26740/jepk.v4n1.p76-91

Wang L, Huang J. 2019. Effect of entrepreneurial self-efficacy on the entrepreneurial intentions of students at a university in Hainan province in China: Taking social support as a moderator. International Journal of Learning, Teaching and Educational Research 18(9):183-200. https:// doi.org/10.26803/ijlter.18.9.10

Wedayanti NPAA, Giantari IGAK. 2016. Peran pendidikan kewirausahaan dalam memediasi pengaruh norma subyektif terhadap niat berwirausaha. E-Jurnal Manajemen 5(1):533560.

Wijaya A, Dharmayanti D. 2016. Pengaruh entrepreneurial orientation terhadap financial performance dengan marketing capability dan organizational learning sebagai variabel intervening pada PT. Asuransi Central Asia di Surabaya. Jurnal Manajemen Pemasaran 10(2):43-51.https://doi.org/10.9744/ pemasaran.10.2.43-51

Winnaar KD, Scholtz F. 2019. Entrepreneurial decision-making: New conceptual perspectives. Management Decision 58(1). https://doi. org/10.1108/MD-11-2017-1152

Wirawati N, Kohardinata C, Vidyanata D. 2018. Analisis sikap kewirausahaan sebagai mediasi antara pendidikan kewirausahaan terhadap intensi kewirausahaan di Universitas Ciputra. Jurnal Performa 3(6):709-720.

Worldometer. 2021. Countries in the world by population. https://www.worldometers.info/ world-population/population-by-country/. [25 June 2021].

Yurtkoru ES, Kuşcu ZK, Doğanay A. 2014. Exploring the antecedents of entrepreneurial intention on Turkish university students. Procedia - Social and Behavioral Sciences 150:841-850. https:// doi.org/10.1016/j.sbspro.2014.09.093 